\title{
The repercussions of the Covid-19 crisis on global markets and the expected scenarios for the advancement of the global economy
}

\author{
Firas Al kufy
}

\author{
Edmonton University, Australia
}

\author{
firassalih@gmail.com
}

\begin{abstract}
The research focuses on assessing and analyzing the impacts of the COVID-19 pandemic and associated impacts on the international market scenarios. Moreover, the research evaluates financial recovery scenarios for global markets to understand the future path of the global economy's progress and overcoming its current distress. Thus, the aim of conducting relevant research is to provide appropriate guidance to various policymakers regarding the development of economic benefits by coordinating global policies to respond effectively to the implications of epidemiological situations associated with COVID-19.

We have monitored many indicators from various countries that seek to overcome the remnants of the epidemic by making use of previous experiences that the world has gone through.

With statistical data, we sought to transfer the idea of increasing national income and reducing inflation to several countries. Finally, we sought to find an appropriate solution to restore the global economy to its previous state in the near future and create an economic market that depends on benefiting from the experiences of countries in this field after the pandemic.
\end{abstract}

Keywords: Pandemic; Global Markets; Financial impact; GDP; Future growth. 


\title{
تداعيات أزمة فيروس كورونا على الأسواق العالمية والسيناريوهات المتوقعة لتقدم الاقتصاد العالمي
}

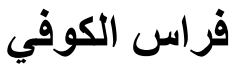 \\ جامعة ادمنتون، استر اليا
}

firassalih@gmail.com

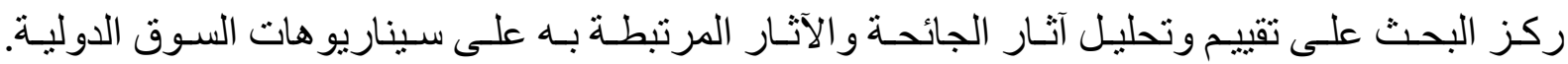

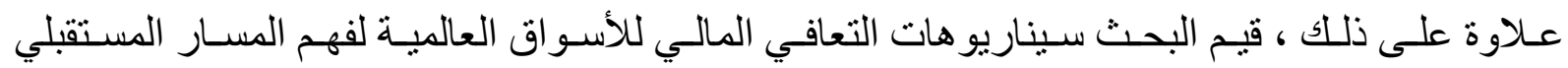

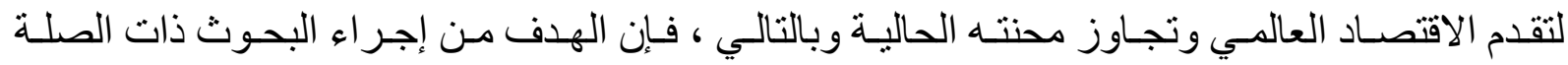

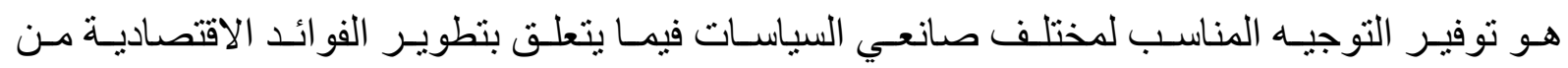

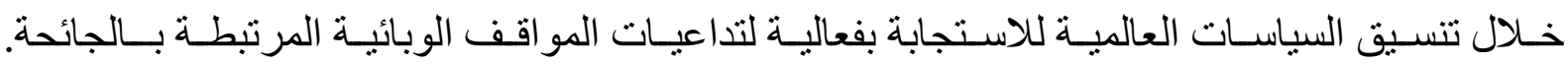

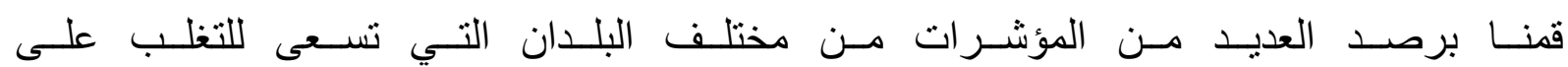

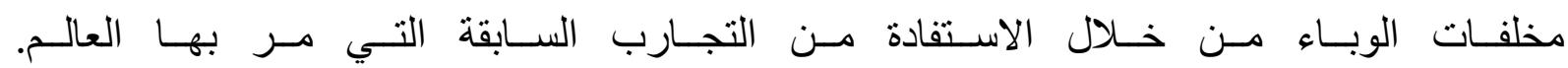

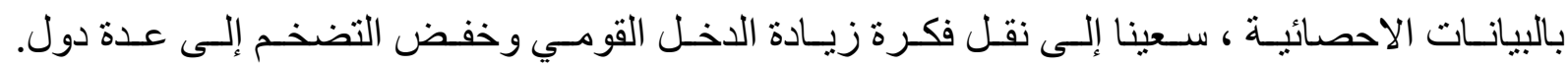

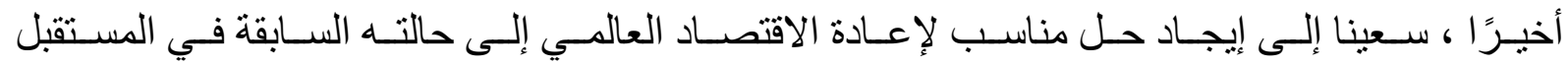

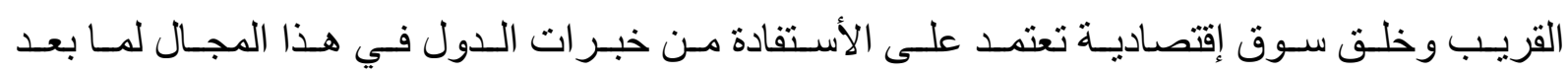
الجائحسة. الكلمات المفتاحية: جائحة؛ الاسواق العالمية؛ الأثر المالي؛ الناتج المحلي الإجمالي؛ النمو المستقبلي. 


\section{Introduction}

The COVID-19 pandemic outbreak, previously acknowledged as the 2019- nCoV, has been caused through the SARS-CoV-2 category of the viral strain. The outbreak had been triggered, initially, at the Wuhan metropolis in the Hubei province of the People's Republic of China (PRC) during December 2019. COVID-19 has consistently expanded throughout the world from the initial epicenter of the PRC. In this context, amidst the significance of public health risks augured in by the COVID-19, the World Health Organisation (WHO) has outlined that the COVID-19 pandemic has constituted the international public health emergency with a scale which requires international coordination of responses to manage and confront the disease. According to Alon et al. (2020), within this extensively interconnected and integrated world, the implications of such a pandemic could transcend the generalized mortality and morbidity perspectives. In case of mortality, the cumulative numbers of deaths which have occurred so far and which would be occurring in the future on account of this disease, are considered in terms of pathological and sociological implications of the viral pandemic. Apart from this, the morbidity prospect, according to Altig et al. (2020), is of greater significance since the pathobiological nature of the Corona Virus has ensured that an extensive number of individuals would be either incapacitated directly through the implications of the disease or would be indirectly incapacitated, in terms of economic and labour perspectives since they would be obliged to care for the infected/incapacitated and thus, would not be active as productive working personnel in their respective national economic frameworks. As per the opinions of Ashraf (2020), this forecast has become apparent within the global financial domain.

To this effect, the corresponding research study would be attempting to quantify the potential global financial impact of the COVID-19 pandemic involving differential economic scenarios. The focus of the subsequent secondary qualitative research process would be concentrated on the evaluation and analysis of repercussions of this COVID-19 pandemic and associated implications of the same on the international market scenario. Furthermore, the research undertaking would also assess the expected financial recovery scenarios of the global market conditions through which the future course of the advancement of the global economy could be comprehended. Thus, the objective of the concerned research undertaking is to provide proper guidance to various policy formulators regarding the development of economic benefits through global policy coordination to effectively respond to implications of COVID-19 related pandemic situations.

In the discourse of secondary research performance, the study undertaking would endeavour to summarise the existing research literature concerning the macroeconomic costs brought about by global pandemics and similar diseases. The objective of such an effort would be to highlight the strengths of macroeconomic scenarios and models. To this effect, the epidemiological infor- 
mation would be required to be adjusted so that the formulation of a proper and comprehensive understanding of various economic scenarios could be developed through which the estimates of shocks to global economic conditions could be forecasted as well. Such forecasting would be of the greatest significance concerning the proper evaluation of implications of developed economic and global market management policies at various levels of market operations.

\section{Pertinent observations concerning existing secondary literature review}

Aslam et al. (2020) have emphasized the disruption of global supply chain management procedures amidst the gradual contraction of international market dynamics and various leading national economies such as that of China. The primary factors have been outlined by Atkeson (2020) to be that of interruptions in production systems. The global contraction in production operations has been contributed to by transportation limitations and restrictions which have been imposed by various nation-states to either completely prevent or arrest the COVID-19 infectious expansion within their respective national territories.

In this context, Baker et al. (2020) observed that panic emanating from the viral pandemic amongst consumers and various business organizations has distorted, to a great extent, the usual patterns of consumption. This particular development has contributed to severe and varied market anomalies as per the global economic condition could be concerned. According to Baker et al. (2020) global financial market conditions have also responded to a varying extent to such anomalies and the effect has been apparent in terms of the decline of global stock indices to the extent which had not been registered since the global financial crisis of 2008-09. Within such global market turbulence, concerning an initial assessment of such effects, the International Monetary Fund (IMF), has forecasted that global GDP growth to slow down by a factor of $0.4 \%$ points in comparison to the initial target of global GDP growth threshold of $5.6 \%$. Thus, it would be an average $0.1 \%$ reduction from the initial estimates. However, such statistics could be subject to post-publication scrutiny and revision by the IMF with the passage of time.

According to Baker et al. (2020), there is a multiplicity of channels through which the influence of any infectious disease outbreak could be imparted on the global and national level economies. From the research perspectives of Baldwin and Weder di Mauro (2020), the direct and indirect implications on the economies of the world, regarding the viral pandemic, are often subject to studies of health economics related to the evaluation of the burden of such infectious diseases. Boumans, Link and Sauer (2020) have determined that any conventional approach regarding health informatics generally utilizes the available information on mortality and morbidity which could preclude or prevent work engagements by affected individuals for the purpose of estimation of future income extents. The variables are death and disability. Furthermore, the incurred losses involving time and income for care providers could be combined with those of direct expenditures which occur regarding the entire medical care discourses provided to COVID-19 infected patients. Such combinations could effectively forecast the overall economic costs which are associated with the detrimental implications of the global Corona 
viral pandemic. However, according to Bradlow and Park (2020), this particular conventional approach generally underestimates the actual financial cost incurrence mechanisms which entail the infectious disease-based economic implications, particularly in congruence to global epidemic proportions. Buheji and Buheji (2020) have concentrated on the research perspective that individual assessment of mortality and economic detrimental risks could be incumbent on the probability of absolute mortality, years of life becoming inactive on account of severe health complications suffered by affected individuals from the after- effects of the contagious viral disease and, most significantly, on the Subjective Discounting Factors (SDF). CapelleBlancard and Desroziers (2020) have specifically ranked Influenza and Pneumonia related viral contagions as the third leading causalities in terms of probability of mortality (after Cancer and cardiovascular maladies). In this context, Cesa-Bianchi, Pesaran and Rebucci (2020) have discussed the research associated with the perspectives of the intention of any individual to remit payment to avoid either death or incapacitation to be proportionate to the probability of suffering uncontrolled and involuntary deaths which are actually dreaded by every individual. Such deaths are mostly associated with extensive externalities and are precipitated through the production of distributional inequity of health benefits and material support elements. Based on such assessments, Chen, Liu and Zhao (2020) have opined that it could not be considered to be an unreasonable assumption that individual perceptions of mortality risks associated with this pandemic-causing virus could be similar to that of the infamous Spanish Influenza which had ravaged the globe a century earlier. The underscoring similarities are the virulence and severity of pathological and clinical symptoms which could be unmanageable, especially during the initial phases of this pandemic when the availability of any credible and effective counter viral medication or antidote to this form of viral contagion could be minimal.

In this context, Corbet, Larkin and Lucey (2020) have observed that the situation is also comparable exactly with that of the reaction brought forward by the global populace during the SARS outbreak during the year 2003-04. The factors are associated with novelty, salience, and public concern regarding the contribution of SARS to the greater than expected intention amongst individuals to undertake payment for prevention of infectivity-related risks from materialization. Previously, as has been outlined by Costa Dias et al. (2020), the conducted studies regarding the macroeconomic effects which had emerged out of the SARS outbreak during 2003 had imparted extensive detrimental implications on multiple national economies through sustained declines in consumption of products and services which did not pertain to the categories of essential commodities, increment in costs of business operations and re- evaluation of risks which could reflect the expansion in rates of risk premiums.

\section{Initial forecasts}

Gössling, Scott and Hall (2020) have examined the studies which have been previously conducted regarding the economic costs of viral pandemics and large-scale contagious outbreaks of different infectious diseases. As per the performed research, the probable economic impacts of the COVID-19 through an early-stage analysis were primarily incumbent upon the expectation of the development of vaccine-based interventions within the near future. However, with the 
passage of time, such expectations have subsided. According to Guan (2020), with a current gross infectivity rate of $355-40 \%$ (standing for numbers of individuals contracting the viral infection out of the entire population of a specific nation such as that of the USA or UK), the numbers of mortality amongst the per thousand ratios has increased from 89 to 270 . This has brought forward the estimated mean total of financial impact-based loss incurrence of the economy of the USA to the extent from $\$ 73.1$ to $\$ 166.5$ billion.

As per the research of McKibbin and Fernando (2020), a particular study conducted by the Congressional Budget Office of the USA has analyzed two particular scenarios of Influenzabased pandemics within the USA. The initial scenario has involved an infectivity rate of $20 \%$ and the case fatality rate of $0.1 \%$ (with the numbers of dead individuals in comparison to the complete numbers of infected individuals). The next scenario has involved an infectivity rate of up to $30 \%$ with a commensurate case-based fatality rate of $2.5 \%$. According to McKibbin and Vines (2020), the primary findings of the studies conducted by the CBO have reflected the estimation of $1.5 \%$ contraction of national GDP of the USA regarding the mild infection scenario and at least $5 \%$ contraction of economic sectors within the USA involving the severe scenario.

The research of McKibbin and Fernando (2020) utilized the vintage model of assessment for the purpose of exploration of 4 different scenarios involving pandemic Influenza. The initial scenario was the Mild consideration which could be compared to that of the 1968-1969 Hong Kong Influenza. The second scenario involved considerations of a Moderate infectious pandemic nature which could be compared to that of Asian Influenza which had occurred during 1957. The Severe scenario was based on the implications of the Spanish Influenza pandemic which had occurred during 1918-1919 with a comparatively lower estimation of case-based fatality rates. The final scenario involved the Ultra nature of the pandemic which also involved the occurrence of Spanish Influenza of 1918-1919, however, with upper-middle estimates involving case- based fatality rates. In this context, McNamara, K.R. and Newman (2020) have delineated that the findings of this research outlined the costs to the international market-based economy to have entailed losses between \$US300 million and \$US4 billion. 


\begin{tabular}{|c|c|}
\hline Countries (20) & Regions (4) \\
\hline$\overline{\text { Argentina }}$ & Rest of the OECD \\
\hline Australia & Rest of Asia \\
\hline Brazil & Other oil-producing countries \\
\hline Canada & Rest of the world \\
\hline \multicolumn{2}{|l|}{ China } \\
\hline Rest of Eurozone & Sectors (6) \\
\hline France & $\overline{\text { Energy }}$ \\
\hline Germany & Mining \\
\hline Indonesia & Agriculture (including fishing and hunting) \\
\hline India & Durable manufacturing \\
\hline Italy & Non-durable manufacturing \\
\hline Japan & Services \\
\hline \multicolumn{2}{|l|}{ Korea } \\
\hline Mexico & Economic Agents in each Countrv (3) \\
\hline Russia & $\overline{\text { A representative household }}$ \\
\hline Saudi Arabia & A representative firm (in each of the 6 production sectors) \\
\hline South Africa & Government \\
\hline \multicolumn{2}{|l|}{ Turkey } \\
\hline \multicolumn{2}{|l|}{ United Kingdom } \\
\hline United States & \\
\hline
\end{tabular}

Figure 1: Enlistment of components of the DSGE with overview of categorisation of the same

(Source: Okorie and Lin, 2020)

Ozili and Arun (2020) have documented the approach which has been embodied within the DSGE model. This particular model, according to Rahman et al. (2020), entails a multiplicity of specific features which could be significant in terms of the development of the proper financial impact of COVID-19 and related estimations. The initial feature is that this model could completely account for shocks and variations in the financial and physical assets. As an instance, Ravindran and Shah (2020) it could be outlined that budgetary deficits could accumulate into various measures of government debts and further into current account deficits which could ultimately accumulate into external and foreign debt prospects. According to Salisu, Akanni and Raheem (2020), this model specifically imposes the inter-temporal budgetary constraints on existing households, governments, business entities, and countries in a similar measure. In this measure, the longer-term based stock equilibrium could obtain the adjustment of prices of existing assets. Examples could be outlined as the interest rates of governmental fiscal policies, positions, and actual exchange rates involving the balance of payment scenarios.

However, Sharfuddin (2020) has highlighted that adjustment of longer-term based equilibrium of individual national economies affected by the pandemic situation could be relatively timeconsuming. This prospect is influenced by the fact that households and business organisations considered within the DSGE model has to rely upon working capital infused in the market by respective central banking organisations of such nations for every transaction cumulatively. 
Thus, the central banking organisations, figured within the model under consideration could determine short term based nominal interest rates so that better influence could be imparted on macroeconomic outcomes encompassing Inflation, Unemployment, Deflation, Stagflation, Exchange Rates, Currency Devaluation, and others. According to Sherif (2020), such macroeconomic influence based short term nominal interest rates is determined on the basis of rules promulgated under the Henderson-McKibbin- Taylor model of monetary operations. Vasiljeva et al. (2020) have argued that such rules have been designed with the objective to approximate monetary control regimes on an individual country basis approach. The monetary norms are utilized to construct and regulate the inflation rates over the longer periods within each of the outlined countries in the DSGE model so that short term policies of adjustment involving controlled fluctuation of the economic scenario could be achieved.

In this context, Verma and Gustafsson (2020) have outlined that nominal wages in these sectors within the DSGE are mostly adjustable over labour contracting assumptions based on the country-specific economic situations. Vidya and Prabheesh (2020) have analysed the pattern of labour recruitment in each of these sectors involves the extent to which the marginal production sequences of labour could be equated with the existing actual wage. Such actual wage is defined through the output price extents concerning the particular sector of operations. However, this approach does have counter criticisms since the excess labour is relegated to enter the unemployed reserve of workers. The objective of such approaches is to enable the nominal wage to become adjusted with that of excess demand so that the labour market-based shock, in the longer terms, could be dissipated. The shortcoming of such an approach could be outlined, from the perspectives of Yang et al. (2020) as the expansion of structural supply shock based unemployment ratio since transformations in the aggregate demand structure could entail such impacts on the economy of any country, developed or developing, in a simultaneous manner.

Apart from these, another factor has been outlined by Zhang, Hu and Ji (2020) as the inherent rigidity of this systematic approach which reflects the difficulties associated with the equilibrium mobility element pertaining to such national economies. Such rigidities primarily include the nominal inflexibilities which are caused through wage rigidities and the dearth of proper foresight in the formulation of expectations. The sustained detrimental effects could be outlined in terms of adjustment of costs of investments within the concerned economies. The reason has been determined by Altig et al. (2020) as the sector-specific nature of physical capital and the adherence of particular monetary and fiscal policies and regulations by respective authorities. Thus, the difference between short term based adjustments to financial shocks precipitated by the COVID-19 pandemic and that of outcomes of longer-term equilibrium is considerably extensive. The focus is primarily on the assessment of the impact of financial policy related rigidities which could become extended over the coming years.

Ultimately, within the DSGE model, the incorporation of heterogeneous households and business organizations is required to model the business entities completely within each of the sectors. Two different categories of consumers and business organizations within each of the sectors are undertaken in terms of assessment. The underscoring principles of selection of such consumer categories are associated with futuristic expectations and adherence to the rules of the thumb which could become optimal in terms of yielding the intended benefits from a perspective approach in the longer terms. 


\section{Utilization of the multi-country based model of threshold effects for study of economic impact of COVID-19 pandemic}

This model is updated enough to consider the cross-sectional and temporal dimensions of financial drivers of global economic activity along with common factors such as petroleum prices and global market volatility. This model could further assist in distinguishing between various multiple common latent factors and the existing trade linkages between the regions considered. The country-specific model emphasizes upon growth outputs, evaluation of real exchange rates, real equity measures, and interest rates over longer terms.

In this context, the shock emanating from COVID-19 could be identified through the utilization of GDP growth forecast revisions of IMF from January to April 2020. The revisions had been caused by the assumption that the COVID-19 pandemic had become the primary catalyst of such forecast revisions. Furthermore, the multi-country based model could assist in the quantification of economic implications of pandemic-related financial shocks through the employment of Generalised Impulse Response Functions methods. The emphasis is firmly concentrated on the evaluation of economic uncertainty and conditional forecast development on the basis of the entire constellation of regional and country-specific financial dynamics and disturbances which have affected the global economy during the entire discourse of COVID-19 based pandemic.

\section{The assessment of COVID-19 on economic dynamics of the global markets}

Ashraf (2020) has averred that several different channels are in existence through which the global volatility could affect future economic recovery and growth prospects considerably. The significance of such channels could be identified as incremental precautionary savings, delayed investment patterns, increment in uncertainty and decline in prospects of demand, comparatively greater costs of growth capital formulation, and considerably higher costs of funding within a generally volatile global market condition. In this context, Aslam et al. (2020) have observed that country-specific analysis through multi- country DSGE model could permit econometric specification through measuring the intercept transformations in growth output statistics along with an estimation of threshold levels and corresponding probabilities which could outline the maximized probability of growth or recovery for both emerging and advanced economies in the separated manner.

DSGE model outlines that the estimated probability threshold for advanced/developed economies is 0.156 on a per quarter basis. This measure is slightly greater than that of the estimated 0.129 which could be assessed in case of emerging market conditions. In this context, it could be considered to be noteworthy that the global volatility had surpassed the 0.156 level in the previous four quarters throughout the prolonged measurement period of 1979Q2 to 2019Q4. This could be better explained that the probability of occurrence of such an event is considered negligible, about $2 \%$. The global economic volatility threshold-based variable is significant from a statistical standpoint within 15 out of 25 advanced economies globally. However, it could be identified that threshold effects are primarily negative in the majority of such advanced economies ( $80 \%$ of assessed cases), as well as in all but 3 of the evaluated emerging/developing market conditions. 

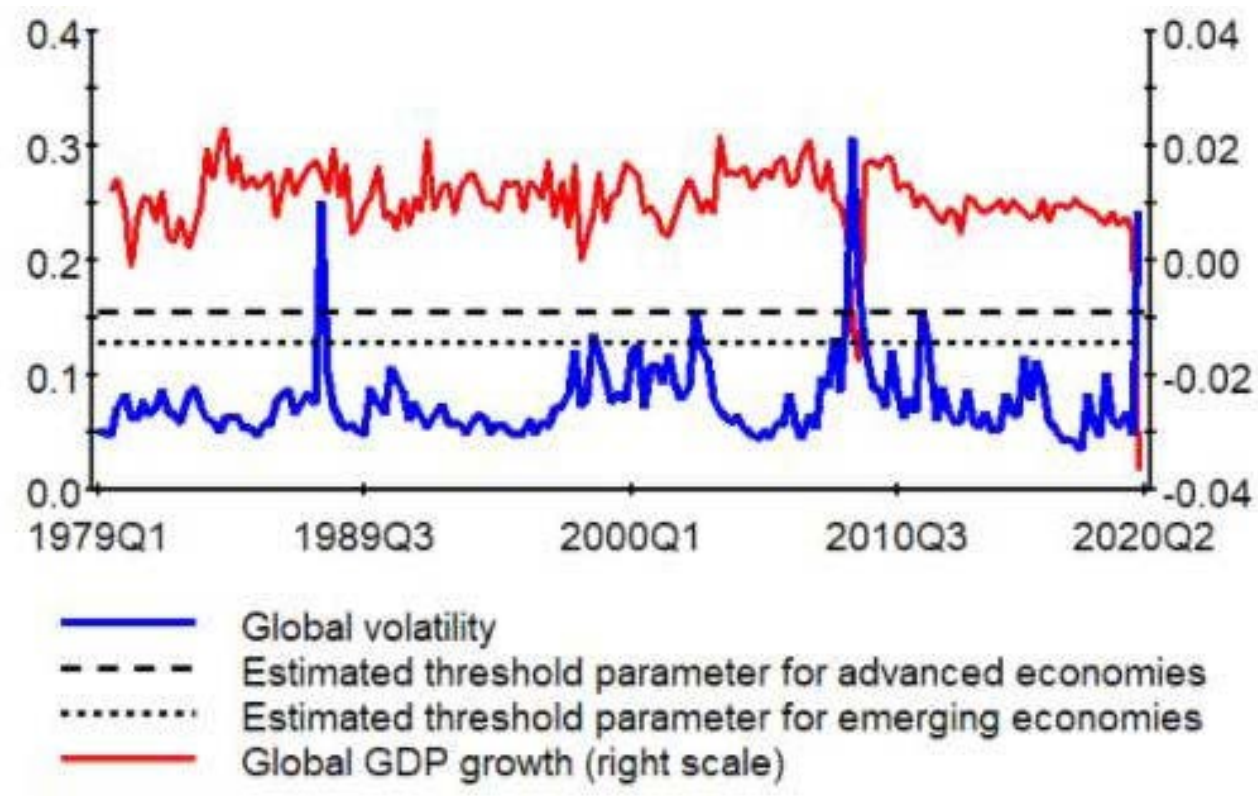

Figure 2: Global volatility implications on GDP growth (baseline 1979Q1 to 2020Q2)

(Source: Atkeson, 2020)

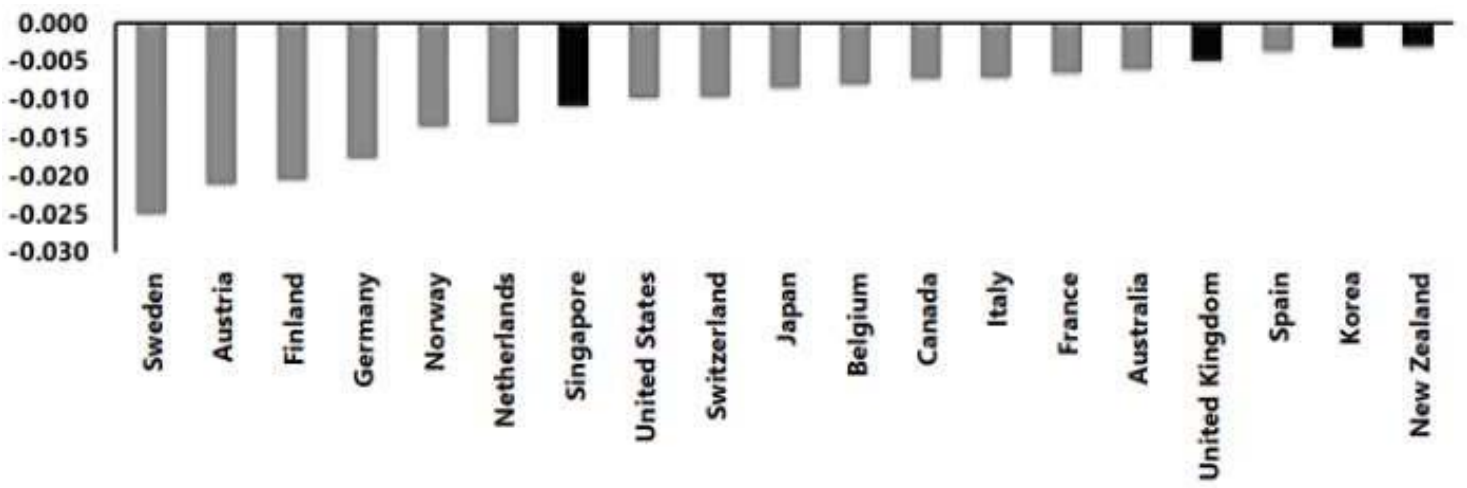

Figure 3: Advanced economy specific GDP volatility threshold effects (baseline 1979Q1 to 2020Q2)

(Source: Baker et al. 2020) 


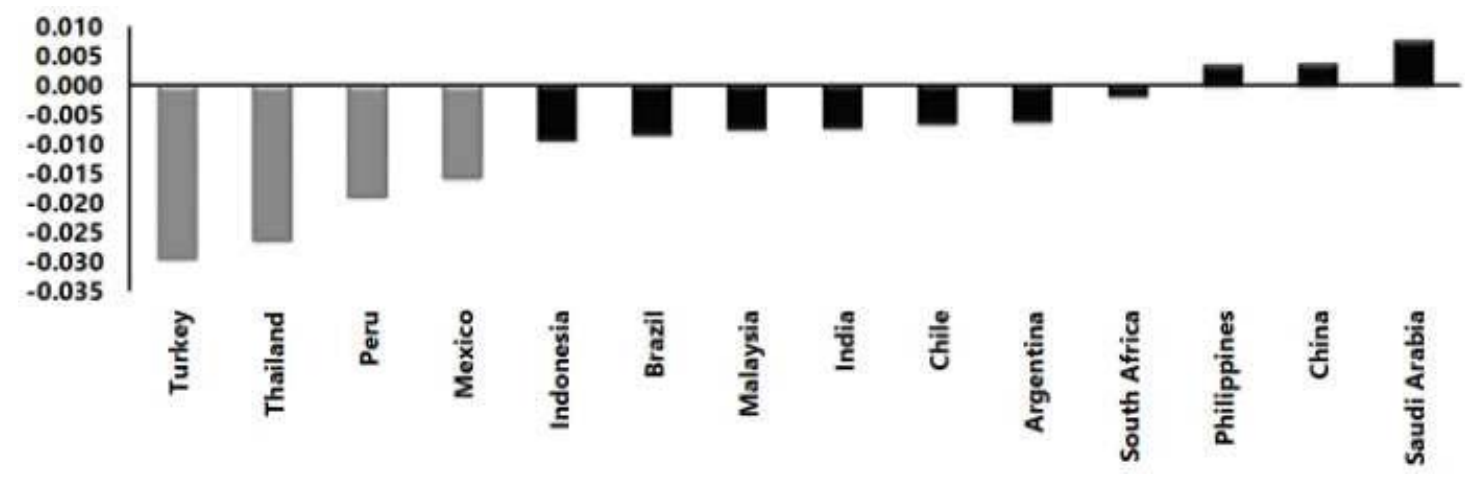

Figure 4: Emerging economy specific GDP volatility threshold effects (baseline 1979Q1 to 2020Q2)

(Source: Baker et al. 2020)

Concerning the significance of the effects of global volatility thresholds regarding subsequent growth output, the estimates could be formulated through the generalized approaches of the DSGE model. The counterfactual analysis

performed through this particular model could outline that COVID-19 is poised to depreciate at least 3\% of points off from the GDP of global markets in comparison to the GDP growth threshold which could have materialized through the situations when the shock emanating from this global pandemic could have been absent. To this effect, the UK and USA are estimated to have the probability of experiencing the longer-lasting and extensive implications of GDP volatility with the projected outcome of $50 \%$ reduction in the Chinese GDP over the outline course of progression. On the other hand, though the odds for the Eurozone are primarily negative in appearance, the probability mass exists which could outline that recovery for this region could be greater in terms of pace in comparison to that of the USA economy by the culmination of the financial year of 2021-22.
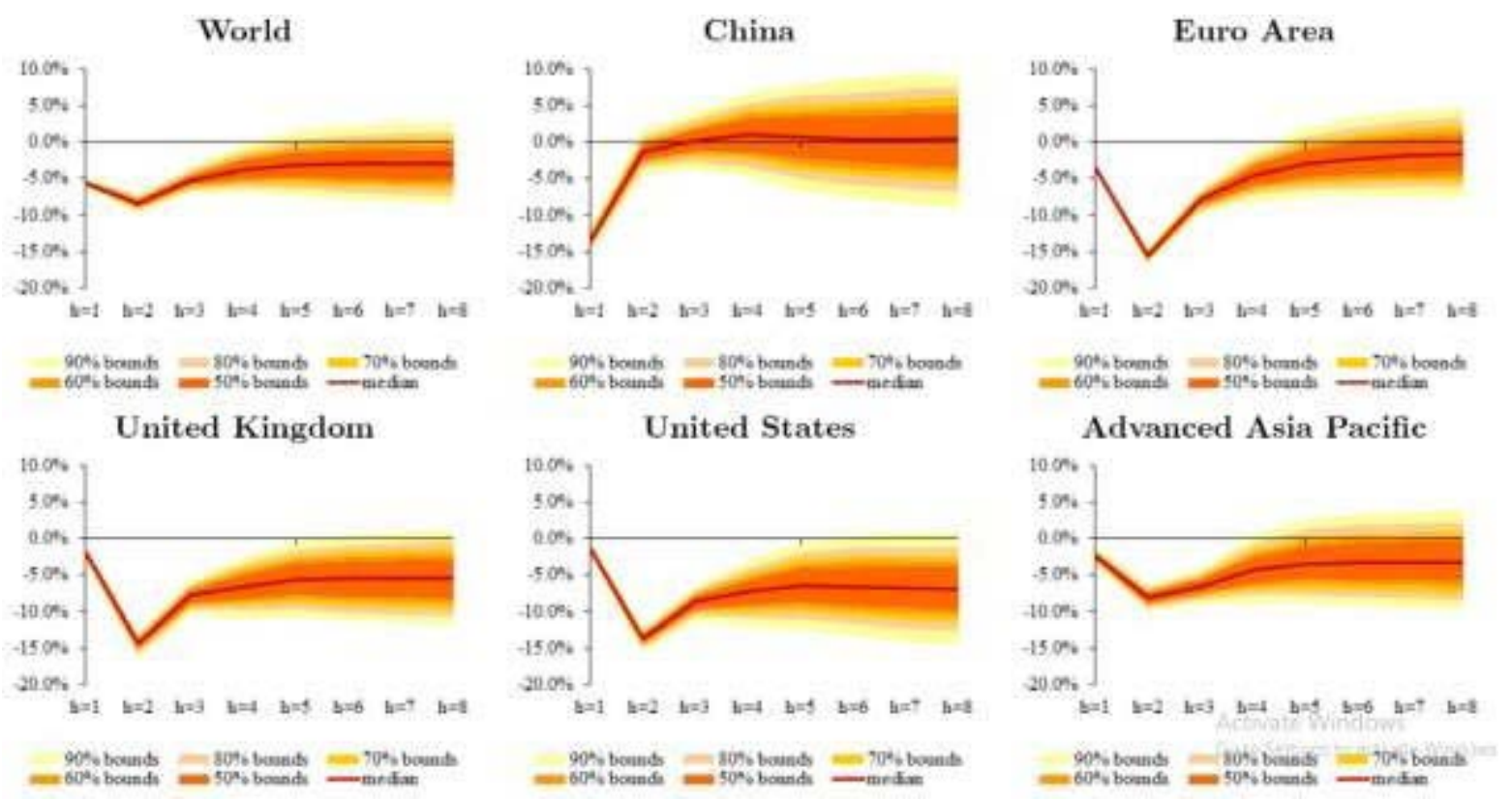

Figure 5: Counterfactual GDP projections during the assessment duration of 2020Q1-2021Q4 (The impact is in percentage and the threshold horizon is considered in quarterly)

(Source: Baker et al. 2020) 
It could be outlined from such analysis that China is pulling the rest of the emergent economies in Asia towards a horizon of better performance in comparison to the global average until the final quarter of 2021. However, emerging markets which are not Asian could have serious vulnerability since there is an extensive probability that they would be suffering from output collapse during the initial and second quarter of 2020 and would further have at least a $30 \%-50 \%$ probability of experiencing output losses by the culmination of 2021. According to Verma and Gustafsson (2020), at least 8 different quarters of severely depressed conditions of the economy would have to be experienced in various emerging markets including Saudi Arabia, South Africa, Turkey, and others.
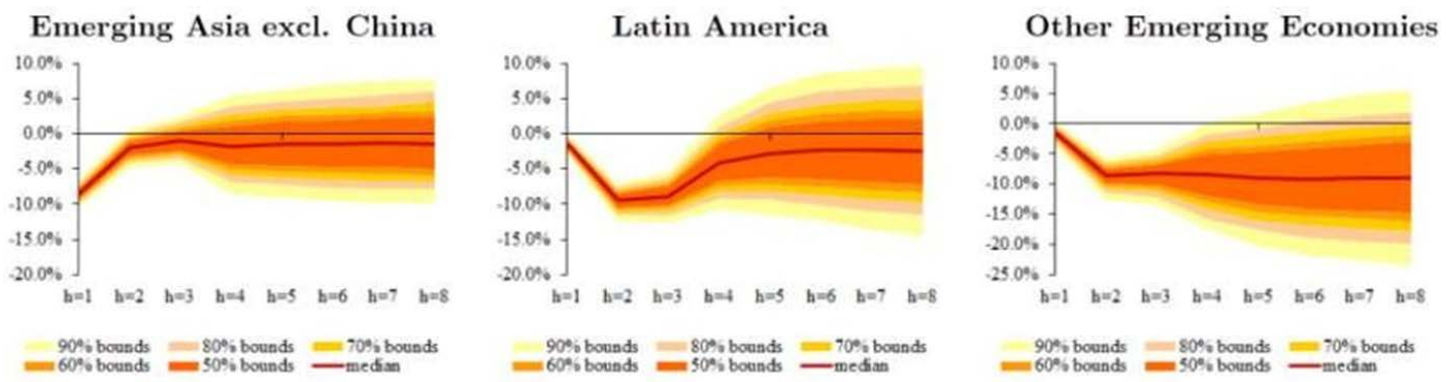

Figure 6: Counterfactual GDP projections involving emerging markets for the duration of 2020Q1-2021Q4 (The impact is in percentage and the threshold horizon is considered in quarterly)

(Source: Baldwin and Weder di Mauro, 2020)

The findings of the DSGE model utilization regarding the assessment of GDP decline forecasts pertaining to multiple countries underscore the spillover effects which could be quantified. This quantification has been undertaken by Baker et al. (2020) in the case of Sweden with considerations of distinctly different approaches of policy management towards the situation of this pandemic. This case has perfectly illustrated that no particular country could be immune to financial fallouts of the COVID-19 pandemic on account of the globalized nature of economic shocks and interconnections.
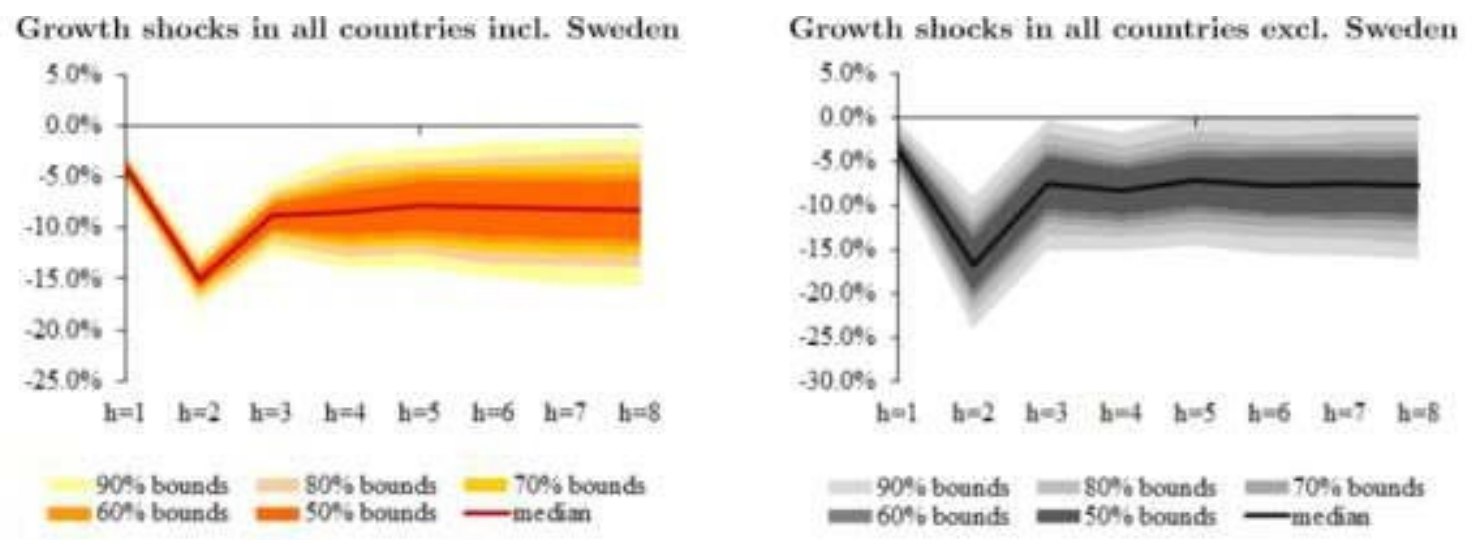

Figure 7: Counterfactual GDP projections concerning the situation of Sweden involving duration of 2020Q1-2021Q4

(Source: Boumans, Link and Sauer, 2020 ) 
According to Bradlow and Park (2020), the DSGE model-based estimates also outline that this pandemic would be imparting long-term implications that are comparatively greater on advanced economies in the range of 100 basis points in comparison to situations that preceded the COVID-19 outbreak. The reason could be outlined as that this pandemic related crisis situation has contributed to extensive practices of precautionary savings on part of consumers and has also dampened the demand for investment. However, such detrimental implications are mostly applicable to advanced market conditions and in the case of emerging market-based economies, such factors are not applicable to the extent which could be observed in cases of advanced economies. The reason has been outlined by Buheji and Buheji (2020) as the rapid increment in borrowing rates which could become prevalent within the emerging economies and this could be demonstrated through the uppermost range of counterfactual assessment associated with the DSGE model.
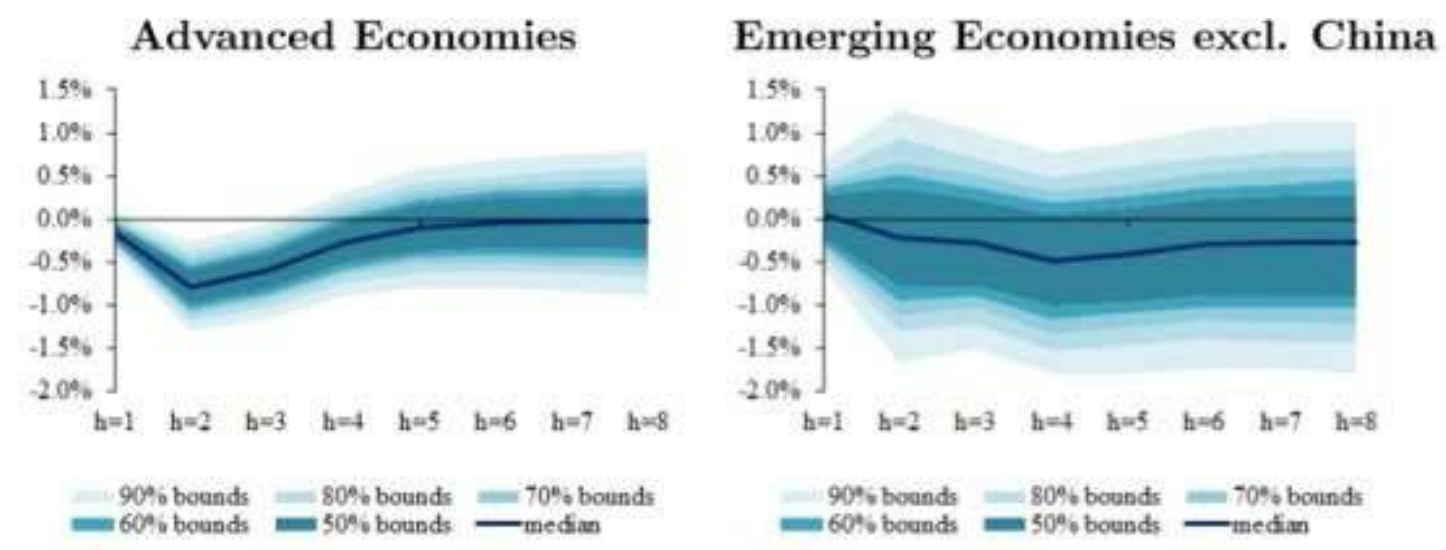

Figure 8: Counterfactual projections for long-term interest rates, 2020Q1- 2021Q4 (percentage points of impacts and quarterly representation through outlined horizon)

(Source: Capelle-Blancard and Desroziers, 2020.)

\section{Implications of COVID-19 on primary GDP aggregates encompassing em- ployment scenario}

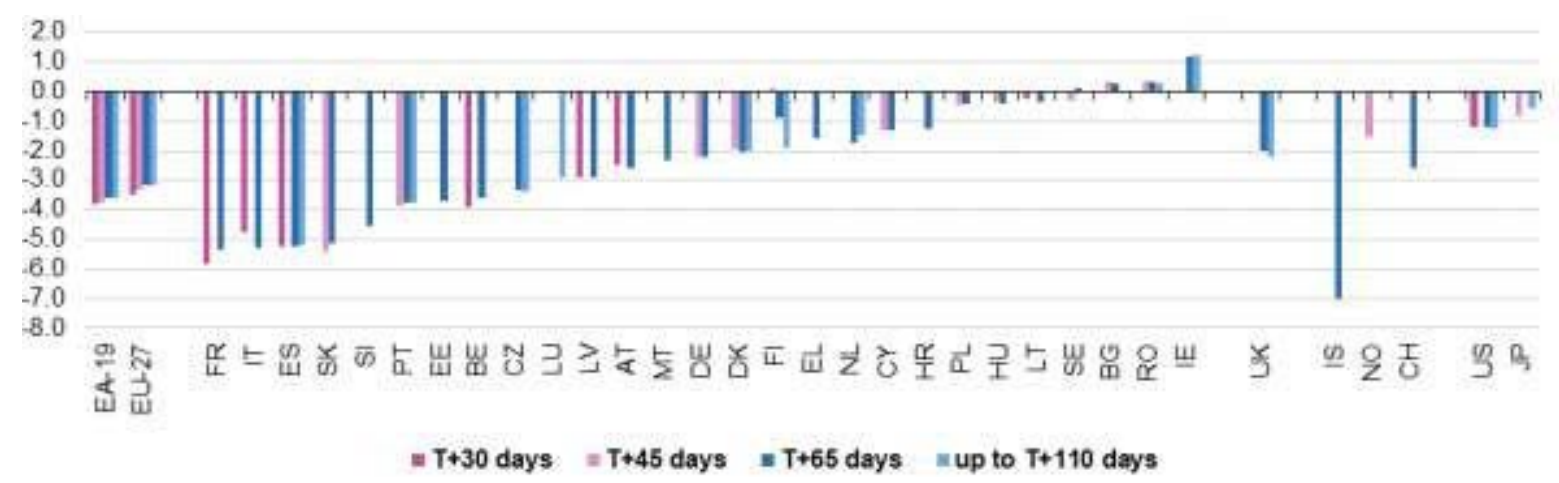

Figure 9: GDP growth rates transformation, on the basis of percentage change in comparison to previous quarter with seasonal dataadjustment

(Source: Chen, Liu and Zhao, 2020) 
The above Figure (9) has presented the GDP quarter to a quarter rate of growth on the basis of seasonal and calendar-based data adjustment for the EU and the Euro Area (EA-19). Apart from these, the EFTA countries and EU member countries, the USA and Japan have been considered and represented as well. The emphasis has been on data which have been published till 20.07.2020. In this context, the research of Corbet, Larkin and Lucey (2020) has sorted the financial data regarding EU member states from the lowest to highest rates of growth for the first quarter of 2020 .

In this context, Costa Dias et al. (2020) have reflected on such latest estimates and have specified that the impact of this pandemic has been most severe on the respective national economies of Italy and France with Spain and Slovakia following at close proximity on the charting table. Only 3 countries, Bulgaria, Ireland and Romania have registered growth rates which are not in the negative domain since these 3 countries have directly been related to activities associated with multinational enterprises. Figure 9 above is also reflective of estimates which have been revised involving some of the countries considered. For instance, Italy and France had published their estimates in a substantially diverging manner at the culmination of April $(\mathrm{T}+30$ days). However, at the culmination of the month of May ( $\mathrm{T}+65$ days), both countries had published similar estimates of declines.

\section{GDP Growth rate revision estimates}

The revisions involving growth rate estimates for EU GDP could be performed only in limited extent since reflections of underlying country-based data could be also limited (encompassing both unpublished and published data extents). The estimate regarding quarter to quarter rate of GDP growth for the Euro area has been $-3.8 \%$ involving $(\mathrm{T}+30)$. This has been confirmed during $(\mathrm{T}+45)$ which was further revised as $-3.5 \%$ during releases till $(\mathrm{T}+65)$ and $(\mathrm{T}+110)$ days. Thus, EU estimates outlined $-3.5 \%$ of GDP growth rate at $(\mathrm{T}+30)$, this was revised as $-3.3 \%$ at $(\mathrm{T}+45)$ and, finally $-3.2 \%$ during the publications at $(\mathrm{T}+65)$ and $(\mathrm{T}+110)$ days.

Elgin, Basbug and Yalaman (2020) have opined, in this context, that such estimates had been revised up to 0.3 percentage points $(\mathrm{PP})$ between the preliminary $\mathrm{T}+30$ publication and the first regular estimates till $(\mathrm{T}+65)$. Regarding the perspective of Gössling, Scott and Hall (2020), this could be considered to be greater than the usually expected one (with a usual range of $+/-0.1 \mathrm{pp}$ during the previous financial year). However, the revisions have remained primarily limited in relative considerations since the process has taken into account the COVID-19 implications as declines in overall GDP in comparison to previous periods of growth and stagnancy. This could be further explained since the growth rates of EU, in terms of net GDP, in previous years (since second quarter of 2013 ) have ranged from $0.1 \%$ to $0.8 \%$. 


\section{Primary GDP expenditure aggregates}

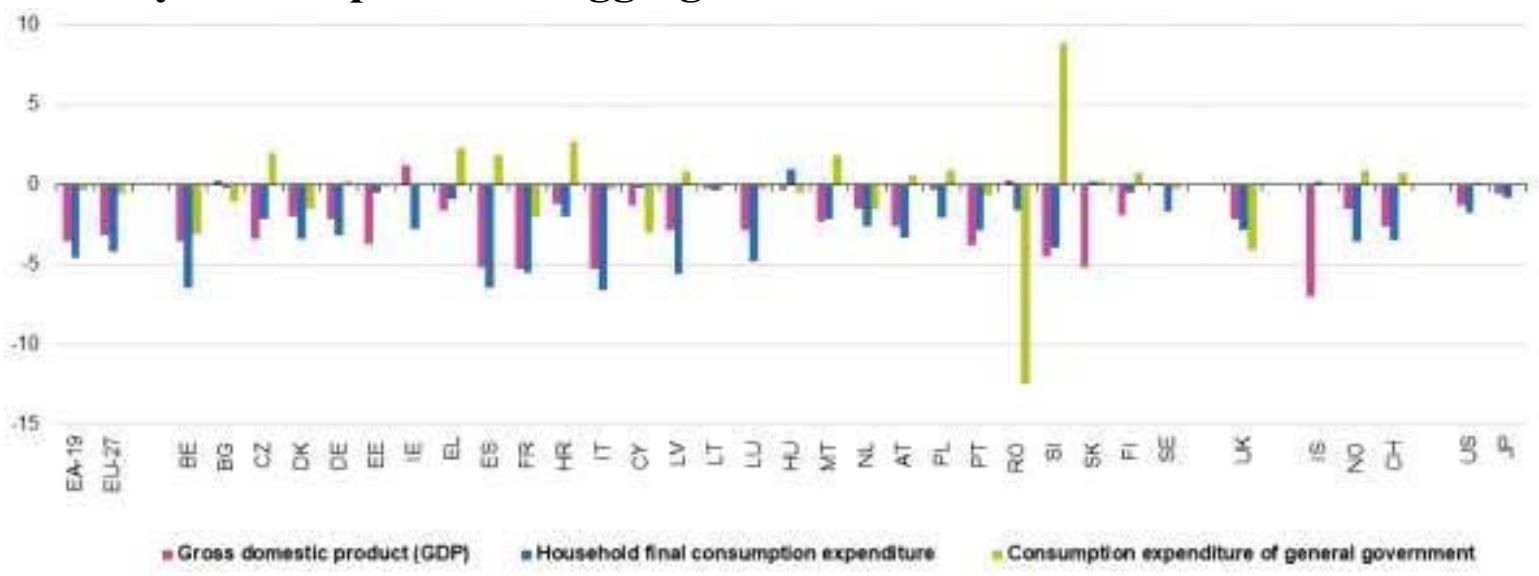

Figure 10: Evolution of GDP expenditure main aggregates during 2020 first quarter

(Source: Guan et al. 2020)

Hall et al. (2020) have noted that decline in individual household-based finalized consumption expenditure, derived from analysis of the GDP expenditure aggregates demonstrated in the above presented Figure 10, has been greater than for GDP of other countries of the G20 (including the China and India). According to Ibn-Mohammed et al (2020), this realization is associated with closure of trade and commercial facilities and restrictions imposition on transportation and mobility introduced in the COVID-19 infected countries so as to arrest the extent of infection. Furthermore, the decline of household consumption and expenditure has been $4.6 \%$ within the Euro area and within the EU it has been $4.2 \%$. The most extensive decline has occurred in case of Italy $(-6.6 \%)$ in comparison to any other EU country. This has been followed by Spain and Belgium (6.5\%). Only Hungary $(+1.0 \%)$ and Slovakia $(+0.2 \%)$ have registered some positive growth rate.

On the other hand, the measure of consumption expenditure involving national governments have demonstrated a condition that outlines significant divergence of outcomes across the entire nationality spectrum of the EU. According to Ivanov and Dolgui (2020), for the Eurozone and EU areas, the general consumptions at governmental levels have declined by $0.4 \%$ and $0.6 \%$ respectively. In case of the EU members, the most significant decline and increment have been registered in countries such as Romania $(-12.5 \%)$ and Slovenia $(+8.9 \%)$. This entire scenario is primarily constituted through genuine differences of implications of COVID-19 pandemic on economic and governmental activities throughout the countries. However, the differences of various methods and sources which have been utilised to obtain the estimates involving specific services and market activities, also constitute such a scenario, though partially. 


\section{Situational outcomes}

According to McKibbin and Vines (2020), the previous experiences that were gathered by national governments and relevant authorities across the world show that it has become possible to exercise a persistently effective caution towards the control measures implemented to arrest the effects of this pandemic. Some of such measures could be outlined as the strengthening of health infrastructure and investments in health screening technology improvement at various national entry points such as ports and border crossings, so as to prevent the contagion from expanding to additional countries. Further responses have been generated in the form of incremental health expenditures to control the viral infectivity. To properly model these interventions undertaken by respective governments, the changes in various government expenditure in relation to the previously achieved GDP measures during each quarterly outbreak scenario have been selected as the benchmark on which averages of Governance and Health Policy Index could be obtained. The purpose is to develop potential forecasts regarding government expenditure which could be undertaken by various countries. Then, the scaling of the findings (in terms of shocks to the economy) could be performed across the expected scenarios through the utilization of the GDP reduction component within the overall economic situational analysis pertaining to the DSGE model.

\begin{tabular}{lllll}
\hline \multicolumn{1}{c}{ Region } & $\mathrm{Q} 1$ & $\mathrm{Q} 2$ & $\mathrm{Q} 3$ & $\mathrm{Q} 4$ \\
\hline Argentina & 0.39 & 0.98 & 1.76 & 0.39 \\
Australia & 0.27 & 0.67 & 1.21 & 0.27 \\
Brazil & 0.39 & 0.98 & 1.76 & 0.39 \\
Canada & 0.26 & 0.66 & 1.19 & 0.26 \\
China & 0.50 & 1.25 & 2.25 & 0.50 \\
France & 0.30 & 0.74 & 1.34 & 0.30 \\
Germany & 0.27 & 0.68 & 1.22 & 0.27 \\
India & 0.52 & 1.30 & 2.34 & 0.52 \\
Indonesia & 0.47 & 1.18 & 2.12 & 0.47 \\
Italy & 0.34 & 0.84 & 1.51 & 0.34 \\
Japan & 0.30 & 0.74 & 1.33 & 0.30 \\
Mexico & 0.43 & 1.07 & 1.93 & 0.43 \\
Republic of Korea & 0.31 & 0.79 & 1.41 & 0.31 \\
Russia & 0.49 & 1.23 & 2.21 & 0.49 \\
Saudi Arabia & 0.38 & 0.95 & 1.71 & 0.38 \\
South Africa & 0.43 & 1.08 & 1.94 & 0.43 \\
Turkey & 0.47 & 1.17 & 2.11 & 0.47 \\
United Kingdom & 0.27 & 0.68 & 1.22 & 0.27 \\
United States of America & 0.22 & 0.54 & 0.98 & 0.22 \\
Other Asia & 0.39 & 0.99 & 1.77 & 0.39 \\
Other oil producing countries & 0.54 & 1.35 & 2.42 & 0.54 \\
Rest of Euro Zone & 0.33 & 0.81 & 1.46 & 0.33 \\
Rest of OECD & 0.28 & 0.70 & 1.26 & 0.28 \\
Rest of the World & 0.59 & 1.49 & 2.67 & 0.59 \\
\hline
\end{tabular}

Figure 11: Government expenditure shocks magnitude

(Source: McKibbin and Fernando, 2020) 


\section{Baseline scenario approach}

This particular approach could be outlined as solving of the observations conducted from Q1 to Q4 2021 with the base year as 2020. The initial epidemiological and economic impact dynamics, emanating from COVID-19 infection, have to be included in the baseline with subsequent projections from

2020 onwards involving labour augmentation technological progression pertaining to individual sectors of each country outlined in Figure 11. Over longer periods, the estimation suggests that the average rate of recovery of individual countries could not exceed $2 \%$ per annum. To this effect, the Groningen Growth and Development methodology could be utilized to properly develop an effective estimate at the initial levels of productivity of sector-based economies and regions. This specific methodology could outline the effectiveness of long term projections of recovery at region specific contexts. However, according to Mofijur et al. (2020), the rate of recovery could invariably be differentiated amongst different countries based on economic reforms (in the case of countries such as China) and institutional centralization and rigidity (such as that of the Russian Federation). Thus, it would be required for any specific model of recovery development to consistently recalibrate the projected forecasts through obtaining information regarding the growth experiences of individual economies, both the advanced and developing ones.

From the perspective of McNamara and Newman (2020), the calibration attempt could entail the replication of growth prospects of country-specific cases. In this context, the observations of Nicola et al (2020) have suggested that the components of growth and recovery of individual economies are primarily 2 in numbers. These are the growth prospect in labour supply and exogenous sectoral rate of productivity and growth of the macroeconomic structure of particular countries. The process highlights that growth within the sectoral capital stock could be determined endogenously as well. 


\begin{tabular}{|c|c|c|c|c|c|c|c|}
\hline Country/Region & Q1 & $\mathrm{Q} 2$ & Q3 & Q4 & Q5 & Q6 & Q7 \\
\hline AUS & -0.3 & -0.4 & -0.7 & -2.1 & -4.6 & -7.9 & -2.0 \\
\hline BRA & -0.3 & -0.3 & -0.5 & -2.1 & -4.7 & -8.0 & -1.9 \\
\hline $\mathrm{CHI}$ & -0.4 & -1.9 & -6.0 & -1.6 & -3.6 & -6.2 & -2.2 \\
\hline IND & -0.2 & -0.2 & -0.4 & -1.4 & -3.1 & -5.3 & -1.3 \\
\hline EUZ & -0.2 & -0.2 & -0.4 & -2.1 & -4.8 & -8.4 & -1.9 \\
\hline FRA & -0.2 & -0.3 & -0.3 & -2.0 & -4.6 & -8.0 & -1.5 \\
\hline DEU & -0.2 & -0.3 & -0.5 & -2.2 & -5.0 & -8.7 & -1.7 \\
\hline $\mathrm{ZAF}$ & -0.2 & -0.2 & -0.4 & -1.8 & -4.0 & -7.0 & -1.5 \\
\hline ITA & -0.2 & -0.3 & -0.4 & -2.1 & -4.8 & -8.3 & -2.2 \\
\hline JPN & -0.3 & -0.4 & -0.5 & -2.5 & -5.7 & -9.9 & -2.0 \\
\hline GBR & -0.2 & -0.2 & -0.3 & -1.5 & -3.5 & -6.0 & -1.2 \\
\hline ROW & -0.2 & -0.2 & -0.3 & -1.5 & -3.5 & -5.9 & -1.5 \\
\hline MEX & -0.1 & -0.1 & -0.1 & -0.9 & -2.2 & -3.8 & -0.9 \\
\hline $\mathrm{CAN}$ & -0.2 & -0.2 & -0.4 & -1.8 & -4.1 & -7.1 & -1.6 \\
\hline OEC & -0.3 & -0.3 & -0.5 & -2.0 & -4.4 & -7.7 & -1.8 \\
\hline OPC & -0.2 & -0.2 & -0.4 & -1.4 & -3.2 & -5.5 & -1.3 \\
\hline ARG & -0.2 & -0.3 & -0.5 & -1.6 & -3.5 & -6.0 & -1.2 \\
\hline RUS & -0.2 & -0.3 & -0.5 & -2.0 & -4.6 & -8.0 & -1.9 \\
\hline SAU & -0.2 & -0.2 & -0.3 & -0.7 & -1.4 & -2.4 & -1.3 \\
\hline TUR & -0.1 & -0.2 & -0.2 & -1.4 & -3.2 & -5.5 & -1.2 \\
\hline USA & -0.1 & -0.1 & -0.2 & -2.0 & -4.8 & -8.4 & -1.5 \\
\hline OAS & -0.1 & -0.2 & -0.4 & -1.6 & -3.6 & -6.3 & -1.5 \\
\hline
\end{tabular}

Figure 12: GDP losses forecast during 2020 (involving deviation from earlier projected baseline)

(Source: Okorie and Lin, 2020) 


\begin{tabular}{|c|c|c|c|c|c|c|c|c|}
\hline \multirow{2}{*}{ Country/Region } & \multirow{2}{*}{$\begin{array}{l}\text { Population } \\
\text { (Thousands) }\end{array}$} & \multicolumn{7}{|c|}{ Mortality in First Year (Thousands) } \\
\hline & & Q1 & Q2 & Q3 & Q4 & Q5 & Q6 & Q7 \\
\hline Argentina & 43,418 & - & - & - & 50 & 126 & 226 & 50 \\
\hline Australia & 23,800 & - & - & - & 21 & 53 & 96 & 21 \\
\hline Brazil & 205,962 & - & - & - & 257 & 641 & 1,154 & 257 \\
\hline Canada & 35,950 & - & - & - & 30 & 74 & 133 & 30 \\
\hline China & $1,397,029$ & 279 & 3,493 & 12,573 & 2,794 & 6,985 & 12,573 & 2,794 \\
\hline France & 64,457 & - & - & - & 60 & 149 & 268 & 60 \\
\hline Germany & 81,708 & - & - & - & 79 & 198 & 357 & 79 \\
\hline India & $1,309,054$ & - & - & - & 3,693 & 9,232 & 16,617 & 3,693 \\
\hline Indonesia & 258,162 & - & - & - & 647 & 1,616 & 2,909 & 647 \\
\hline Italy & 59,504 & - & - & - & 59 & 147 & 265 & 59 \\
\hline Japan & 127,975 & - & - & - & 127 & 317 & 570 & 127 \\
\hline Mexico & 125,891 & - & - & - & 184 & 460 & 828 & 184 \\
\hline Republic of Korea & 50,594 & - & - & - & 61 & 151 & 272 & 61 \\
\hline Russia & 143,888 & - & - & - & 186 & 465 & 837 & 186 \\
\hline Saudi Arabia & 31,557 & - & - & - & 29 & 71 & 128 & 29 \\
\hline South Africa & 55,291 & - & - & - & 75 & 187 & 337 & 75 \\
\hline Turkey & 78,271 & - &. & . & 116 & 290 & 522 & 116 \\
\hline United Kingdom & 65,397 & - & - & - & 64 & 161 & 290 & 64 \\
\hline United States of America & 319,929 & - & - & - & 236 & 589 & 1,060 & 236 \\
\hline Other Asia & 330,935 & - & - & - & 530 & 1,324 & 2,384 & 530 \\
\hline Other oil producing countries & 517,452 & - & - & - & 774 & 1,936 & 3,485 & 774 \\
\hline Rest of Euro Zone & 117,427 & - & - & - & 106 & 265 & 478 & 106 \\
\hline Rest of OECD & 33,954 & - & - & - & 27 & 67 & 121 & 27 \\
\hline Rest of the World & $2,505,604$ & - & - & - & 4,986 & 12,464 & 22,435 & 4,986 \\
\hline Total & $7,983,209$ & 279 & 3,493 & 12,573 & 15,188 & 37,971 & 68,347 & 15,188 \\
\hline
\end{tabular}

Figure 13: Population based impact of COVID-19 on a country specific scenario (Projections of mortality specifics)

(Source: Ozili and Arun, 2020) 


\section{Conclusion}

At the conclusive phase, it could be outlined that the previous analysis has enumerated the significance of the balance of trade between the developed and developing economies as a possible remedy of staving off such economic detrimental effects which have been brought forth by COVID-19. Sherif (2020) has stressed the fact that the reformation of the trade balance between the USA and China could be interpreted as the global reallocation of growth finance capital as a direct outcome of the economic shock which has been precipitated through the viral pandemic crisis. Such capital is currently flowing out of countries which have been severely affected by the pandemic (encompassing both emerging and developed economies) to comparatively safer destinations within Asia, Europe, and Australia. The appreciation and depreciation of exchange rates could thus be observed throughout the globe involving countries which are the recipients of such growth capital and others which are currently having to relinquish such capital. Exports are primarily increased with the deprecation of exchange rates with a reduction of imports. Thus, for severely affected countries, the adjustment of current account deficits could become consistent with that of adjusting the capital account. 


\section{Reference List}

1. Isabelle, Y.L 2020. Managing global liquidity through COVID-19 and beyond. Chatham House, Managing Director, BlackRock (No .w4338 ) .Corona Virus Panademic .

2. Williams, D., (2019). UAE Signs on to Panademic plan. Chemanager-Online. Available from https:/www.chemanager-online.com/en/news- opinions/headlines/uae-signs- after COVID -19 plan [Accessed on 11/08/2020]

3. Alon, T.M., Kim, M., Lagakos, D. and VanVuren, M., 2020. How Should Policy Responses to the COVID-19 Pandemic Differ in the Developing World? (No. w27273). National Bureau of Economic Research.

4. Altig, D., Baker, S., Barrero, J.M., Bloom, N., Bunn, P., Chen, S., Davis, S.J., Leather, J., Meyer, B., Mihaylov, E. and Mizen, P., 2020. Economic uncertainty before and during the COVID-19 pandemic. Journal of Public Economics, 191, p.104274.

5. Ashraf, B.N., 2020. Economic impact of government interventions during the COVID-19 pandemic: International evidence from financial markets. Journal of Behavioral and Experimental Finance, 27, p.100371.

6. Aslam, F., Aziz, S., Nguyen, D.K., Mughal, K.S. and Khan, M., 2020. On the Efficiency of Foreign Exchange Markets in times of the COVID-19 Pandemic. Technological forecasting and social change, 161, p.120261.

7. Atkeson, A., 2020. What will be the economic impact of covid-19 in the us? rough estimates of disease scenarios (No. w26867). National Bureau of Economic Research.

8. Baker, S.R., Bloom, N., Davis, S.J. and Terry, S.J., 2020. Covid-induced economic uncertainty (No. w26983). National Bureau of Economic Research.

9. Baker, S.R., Bloom, N., Davis, S.J., Kost, K., Sammon, M. and Viratyosin, T., 2020. The unprecedented stock market reaction to COVID-19. The Review of Asset Pricing Studies.

10. Baker, S.R., Bloom, N., Davis, S.J., Kost, K.J., Sammon, M.C. and Viratyosin, T., 2020. The unprecedented stock market impact of COVID-19 (No. w26945). National Bureau of Economic Research.

11. Baker, S.R., Farrokhnia, R.A., Meyer, S., Pagel, M. and Yannelis, C., 2020. How does household spending respond to an epidemic? consumption during the 2020 covid-19 pandemic (No. w26949). National Bureau of Economic Research.

12. Baldwin, R. and Weder di Mauro, B., 2020. Economics in the Time of COVID- 19.

13. Boumans, D., Link, S. and Sauer, S., 2020. COVID-19: The world economy needs a lifeline-but which one? (No. 27). EconPol Policy Brief. 
The repercussions of the Covid-19 crisis on global markets and the expected scenarios for the advancement of the global economy

14. Bradlow, D.D. and Park, S.K., 2020. A Global Leviathan Emerges: The Federal Reserve, COVID-19, and International Law. American Journal of International Law, 114(4), pp.657665 .

15. Buheji, M. and Buheji, A., 2020. Planning Competency in the New Normal- Employability Competency in Post-COVID-19 Pandemic. International Journal of Human Resource Studies, 10(2), pp.237-251.

16. Capelle-Blancard, G. and Desroziers, A., 2020. The stock market is not the economy? Insights from the COVID-19 crisis. Insights from the COVID-19 Crisis (June 16, 2020). CEPR Covid Economics.

17. Cesa-Bianchi, A., Pesaran, M.H. and Rebucci, A., 2020. Uncertainty and economic activity: A multicountry perspective. The Review of Financial Studies, 33(8), pp.3393-3445.

18. Chen, C., Liu, L. and Zhao, N., 2020. Fear sentiment, uncertainty, and bitcoin price dynamics: The case of COVID-19. Emerging Markets Finance and Trade, 56(10), pp.2298-2309.

19. Corbet, S., Larkin, C. and Lucey, B., 2020. The contagion effects of the covid-19 pandemic: Evidence from gold and cryptocurrencies. Finance Research Letters, p.101554.

20. Costa Dias, M., Joyce, R., Postel-Vinay, F. and Xu, X., 2020. The challenges for labour market policy during the Covid-19 pandemic. Fiscal Studies, 41(2), pp.371-382.

21. Dietrich, A., Keuster, K., Müller, G.J. and Schoenle, R., 2020. News and uncertainty about covid-19: Survey evidence and short-run economic impact.

22. Elgin, C., Basbug, G. and Yalaman, A., 2020. Economic policy responses to a pandemic: Developing the COVID-19 economic stimulus index. Covid Economics, 1(3), pp.40-53.

23. Gössling, S., Scott, D. and Hall, C.M., 2020. Pandemics, tourism and global change: a rapid assessment of COVID-19. Journal of Sustainable Tourism, pp.1-20.

24. Guan, D., Wang, D., Hallegatte, S., Huo, J., Li, S., Bai, Y., Lei, T., Xue, Q., Davis, S.J., Coffman, D.M. and Cheng, D., 2020. Global economic footprint of the COVID-19 pandemic.

25. Hall, M.C., Prayag, G., Fieger, P. and Dyason, D., 2020. Beyond panic buying: consumption displacement and COVID-19. Journal of Service Management.

26. Ibn-Mohammed, T., Mustapha, K.B., Godsell, J.M., Adamu, Z., Babatunde, K.A., Akintade, D.D., Acquaye, A., Fujii, H., Ndiaye, M.M., Yamoah, F.A. and Koh, S.C.L., 2020. A critical review of the impacts of COVID-19 on the global economy and ecosystems and opportunities for circular economy strategies. Resources, Conservation and Recycling, p.105169.

27. Ivanov, D. and Dolgui, A., 2020. Viability of intertwined supply networks: extending the supply chain resilience angles towards survivability. A position

28. paper motivated by COVID-19 outbreak. International Journal of Production Research, 
58(10), pp.2904-2915.

29. Kristinae, V., Wardana, I., Giantari, I. and Rahyuda, A., 2020. The role of powerful business strategy on value innovation capabilities to improve marketing performance during the COVID-19 pandemic. Uncertain Supply Chain Management, 8(4), pp.675-684.

30. McKibbin, W. and Fernando, R., 2020. The economic impact of COVID-

31. Economics in the Time of COVID-19, 45.

32. McKibbin, W. and Vines, D., 2020. Global macroeconomic cooperation in response to the COVID-19 pandemic: a roadmap for the G20 and the IMF. Oxford Review of Economic Policy, 36(Supplement_1), pp.S297-S337.

33. McKibbin, W.J. and Fernando, R., 2020. The global macroeconomic impacts of COVID-19: Seven scenarios.

34. McNamara, K.R. and Newman, A.L., 2020. The Big Reveal: COVID-19 and Globalization's Great Transformations. International Organization, pp.1-19.

35. Mofijur, M., Fattah, I.R., Alam, M.A., Islam, A.S., Ong, H.C., Rahman, S.A., Najafi, G., Ahmed, S.F., Uddin, M.A. and Mahlia, T.M.I., 2020. Impact of COVID-19 on the social, economic, environmental and energy domains: Lessons learnt from a global pandemic. Sustainable Production and Consumption.

36. Nicola, M., Alsafi, Z., Sohrabi, C., Kerwan, A., Al-Jabir, A., Iosifidis, C., Agha, M. and Agha, R., 2020. The socio-economic implications of the coronavirus

37. pandemic (COVID-19): A review. International journal of surgery (London, England), 78, p.185.

38. Okorie, D.I. and Lin, B., 2020. Stock Markets and the COVID-19 Fractal Contagion Effects. Finance Research Letters, p.101640.

39. Ozili, P.K. and Arun, T., 2020. Spillover of COVID-19: impact on the Global Economy. Available at SSRN 3562570.

40. Rahman, M.A., Zaman, N., Asyhari, A.T., Al-Turjman, F., Bhuiyan, M.Z.A. and Zolkipli, M.F., 2020. Data-driven dynamic clustering framework for mitigating the adverse economic impact of Covid-19 lockdown practices. Sustainable Cities and Society, 62, p. 102372 .

41. Ravindran, S. and Shah, M., 2020. Unintended consequences of lockdowns: Covid-19 and the shadow pandemic (No. w27562). National Bureau of Economic Research.

42. Salisu, A.A., Akanni, L. and Raheem, I., 2020. The COVID-19 global fear index and the predictability of commodity price returns. Journal of Behavioral and Experimental Finance, 27, p.100383. 
43. Sharfuddin, S., 2020. The world after Covid-19. The Round Table, 109(3), pp.247-257.

44. Sherif, M., 2020. The impact of Coronavirus (COVID-19) outbreak on faith- based investments: An original analysis. Journal of Behavioral and Experimental Finance, p.100403.

45. Vasiljeva, M., Neskorodieva, I., Ponkratov, V., Kuznetsov, N., Ivlev, V., Ivleva, M., Maramygin, M. and Zekiy, A., 2020. A Predictive Model for Assessing the Impact of the COVID-19 Pandemic on the Economies of Some Eastern European Countries. Journal of Open Innovation: Technology, Market, and Complexity, 6(3), p.92.

46. Verma, S. and Gustafsson, A., 2020. Investigating the emerging COVID-19 research trends in the field of business and management: A bibliometric analysis approach. Journal of Business Research, 118, pp.253-261.

47. Vidya, C.T. and Prabheesh, K.P., 2020. Implications of COVID-19 pandemic on the global trade networks. Emerging Markets Finance and Trade, 56(10), pp.2408-2421.

48. Yang, C., Sha, D., Liu, Q., Li, Y., Lan, H., Guan, W.W., Hu, T., Li, Z., Zhang, Z., Thompson, J.H. and Wang, Z., 2020. Taking the pulse of COVID-19: A spatiotemporal perspective. International Journal of Digital Earth, 13(10), pp.1186-1211.

49. Zhang, D., Hu, M. and Ji, Q., 2020. Financial markets under the global pandemic of COVID-19. Finance Research Letters, p.101528. 